\title{
In The Line of Treatment: A Systematic Review of Paroxysmal Supraventricular Tachycardia
}

Farrukh Ahmad ${ }^{1,2}$, Majdi Abu Sneineh ${ }^{3}$, Ravi S. Patel ${ }^{3}$, Sai Rohit Reddy ${ }^{3}$, Adiona Llukmani ${ }^{4}$, Ayat Hashim $^{5}$, Dana R. Haddad ${ }^{6}$, Domonick K. Gordon ${ }^{3}$

1. Emergency Medicine, California Institute of Behavioral Neurosciences \& Psychology, Fairfield, USA 2. Emergency Medicine, Beaumont Hospital, Dublin, IRL 3. Internal Medicine, California Institute of Behavioral Neurosciences \& Psychology, Fairfield, USA 4. Medical Education and Simulation, California Institute of Behavioral Neurosciences \& Psychology, Fairfield, USA 5. Internal Medicine/Pediatrics, California Institute of Behavioral Neurosciences \& Psychology, Fairfield, USA 6. Plastic and Reconstructive Surgery, California Institute of Behavioral Neurosciences \& Psychology, Fairfield, USA

Corresponding author: Farrukh Ahmad, drfac2000@yahoo.com

\begin{abstract}
Paroxysmal supraventricular tachycardia (PSVT) is a common tachyarrhythmia, and an electrocardiogram is the best tool for making a diagnosis. If Valsalva maneuvers and carotid sinus massage do not give positive results, then the next choice is either adenosine or calcium channel blockers. At this time, adenosine is the drug of choice of treatment. Verapamil and diltiazem are the most commonly used calcium channel blockers (CCBs). This review aimed to compare the efficacy of both drugs in the treatment of PSVT.
\end{abstract}

We utilized the databases PubMed Central and Medline by using keywords: "calcium channel blockers OR adenosine AND supraventricular tachycardia." In the end, we finalized 32 studies, including observational studies, literature reviews, systematic reviews/metanalysis, and randomized control trials. We included articles only in the English language and related to humans. Two authors completed the quality assessment and evaluation of bias according to specific guidelines. Only high-quality studies were included in this systematic review based on the cut-off score of seven or above. Calcium channel blockers have a longer halflife than adenosine and were previously used as the drug of choice in the treatment of PSVT. Calcium channel blockers are safe if given slowly; however, adenosine is safer and useful when an electrocardiogram is uncertain. We compared both drugs in certain aspects and found equal efficacy. Though safer, adenosine was found to have a higher cost and a higher probability of re-initiation arrhythmia compared to calcium channel blockers.

Received 02/26/2021 Review began 05/12/2021 Review ended 05/22/2021 Published 06/07/2021

\section{() Copyright 2021}

Ahmad et al. This is an open access article distributed under the terms of the Creative Commons Attribution License CC-BY 4.0., which permits unrestricted use, distribution, and reproduction in any medium, provided the original author and source are credited.
Categories: Cardiology, Emergency Medicine, Internal Medicine

Keywords: calcium channel blockers, adenosine, supraventricular tachycardia

\section{Introduction And Background}

According to the Heart Rhythm Society, millions of individuals encounter unusual heartbeats at some stage in their lives. Most of the time, they are safe and happen in individuals free of heart illnesses. However, a few abnormal heart rhythms can be genuine or indeed dangerous. Having underlying heart disease can also increase the chance of arrhythmias [1].

Paroxysmal supraventricular tachycardia (PSVT) alludes to fast rhythms that start and is sustained in atrial or atrioventricular hub tissue over the bundle of His. PSVT is caused by re-entry phenomena or automaticity at or over the atrioventricular node. PSVT includes atrioventricular nodal re-entrant tachycardia (AVNRT), atrioventricular reciprocating tachycardia (AVRT), atrial tachycardia (AT), and a few more tachyarrhythmias [2]. Accelerated rhythms can be terrifying to the patient and can cause significant morbidity. AVNRT is the most common type of paroxysmal SVT, followed by AVRT [3]. For patients presenting with PSVT, a 12-lead electrocardiogram (ECG) showing a narrow complex tachycardia is the basis for making the diagnosis and uncovering the arrhythmia mechanism [4]. In pregnancy, the most common tachyarrhythmia is AVNRT [5]. There are a few treatment choices for PSVT, as seen in Figure 1. 


\section{Cureus}

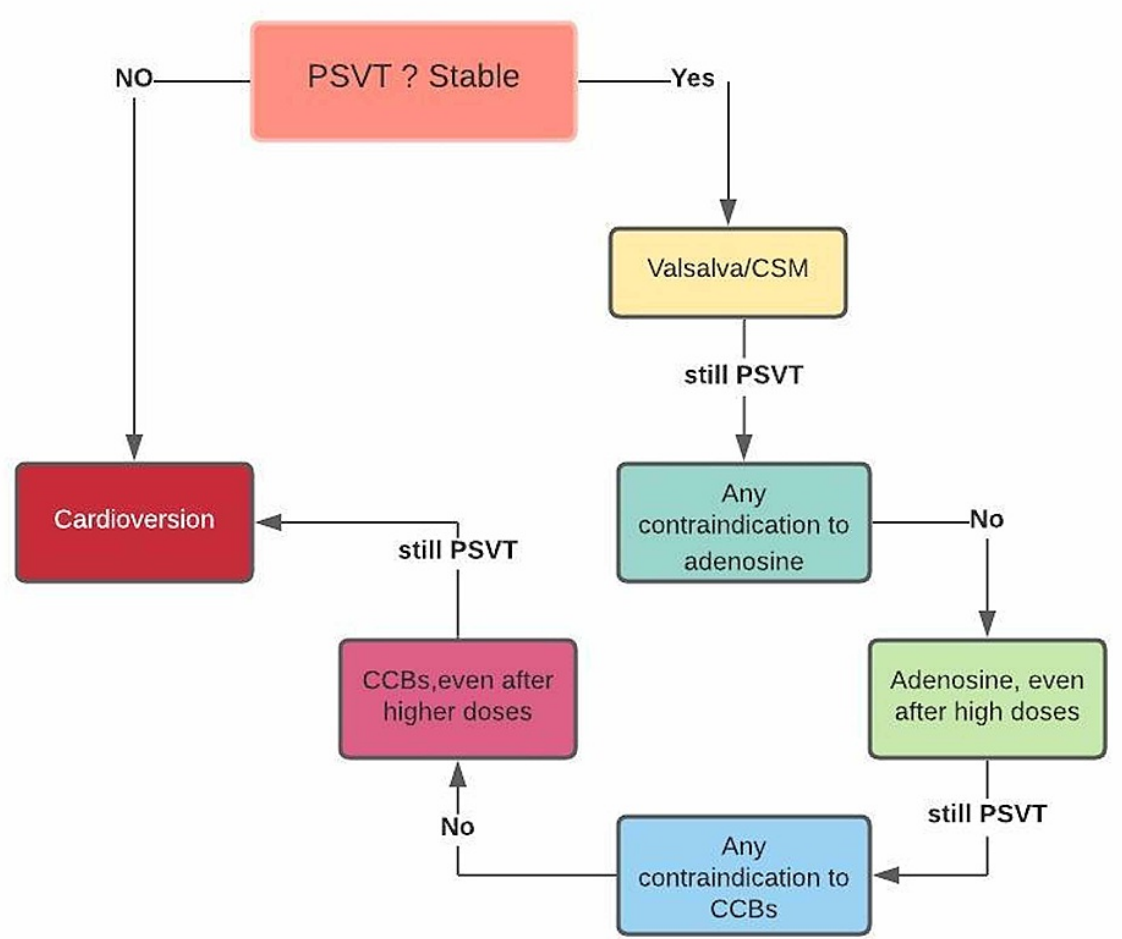

FIGURE 1: Treatment Options for Paroxysmal Supraventricular Tachycardia

PSVT= paroxysmal supraventricular tachycardia, $\mathrm{CCBs}=$ calcium channel blockers, $\mathrm{CSM}=$ carotid sinus massage

The most commonly performed initial treatment is the Valsalva maneuver and carotid sinus massage (CSM). The increase in intra-thoracic pressure from these maneuvers can stimulate aortic and carotid baroreceptors, causing an increased firing of vagal input into the atrioventricular hub [6]. Failure of CSM could be due to inadequately performed massage and a decrease in the response of PSVT over time [7]. When these specific maneuvers are unsuccessful, PSVT can be treated within the emergency department with an assortment of various drugs. PSVT is more common in women than men, with an average age of around 55 years [8].

Adenosine is an endogenous nucleoside with a half-life of less than a minute, which acts by repressing calcium influx and improving potassium conduction. Adenosine leads to inhibition of atrioventricular (AV) nodal conduction and increases the AV nodal refractory period. Due to its brief half-life, reversion to sinus beat may be short-lived as an ensuing ectopic beat may re-initiate SVT. Numerous patients encounter shortlived but exceptionally unpleasant side impacts after adenosine administration, such as dyspnoea, flushing, and a sense of impending doom that may be incredibly frightening [9]. Adenosine though more expensive than other intravenous medications is still the drug of choice [10].

Calcium channel blockers (CCBs) like verapamil inhibit calcium ion influx in direct proportion to its concentration in plasma. It has a bioavailability of $20-35 \%$, has no or few active metabolites, eliminated by extra-renal routes, and has a plasma half-life of three to six hours. It reaches its peak plasma level in one to two hours [11]. CCBs can cause negative inotropy and peripheral vasodilation resulting in hypotension, particularly in patients with impaired left ventricular function [9]. If there is a hemodynamic compromise in patients with PSVT, then the best option is direct current cardioversion [12].

This review aims to compare different aspects of both drugs, such as reversion rate to normal sinus rhythm, time to immediate reversion to sinus rhythm, cost of medicine, minor and major side effects, recurrence of arrhythmia, and the better option. We also aim to determine if oral CCB is a suitable alternative after the failed termination of PSVT with adenosine.

\section{Review}

This systematic review compared calcium channel blockers versus adenosine in the treatment of 


\section{Cureus}

supraventricular tachycardia. We followed the Preferred Reporting Items for Systematic Reviews and MetaAnalyses (PRISMA) guidelines.

\section{Methods}

The search included the electronic databases Medline and PubMed Central. The keywords used in the search process included "calcium channel blockers OR adenosine AND supraventricular tachycardia" and ("calcium channel blockers" [MeSH major topic] OR "adenosine" [MeSH major topic]) AND "tachycardia,

supraventricular" [MeSH major topic], medical subject headings (MeSH) strategy, used. There were 1339 articles identified from November 1972 to December 26, 2020. After applying our inclusion/exclusions criteria, which consisted of only humans and the English language, the number of articles reduced to 989. Mendeley citation manager was used to remove duplicated studies. In the end, 954 studies were excluded on the basis of title and abstract and 32 were retained. Figure 2 below shows the search strategy PRISMA flow diagram.
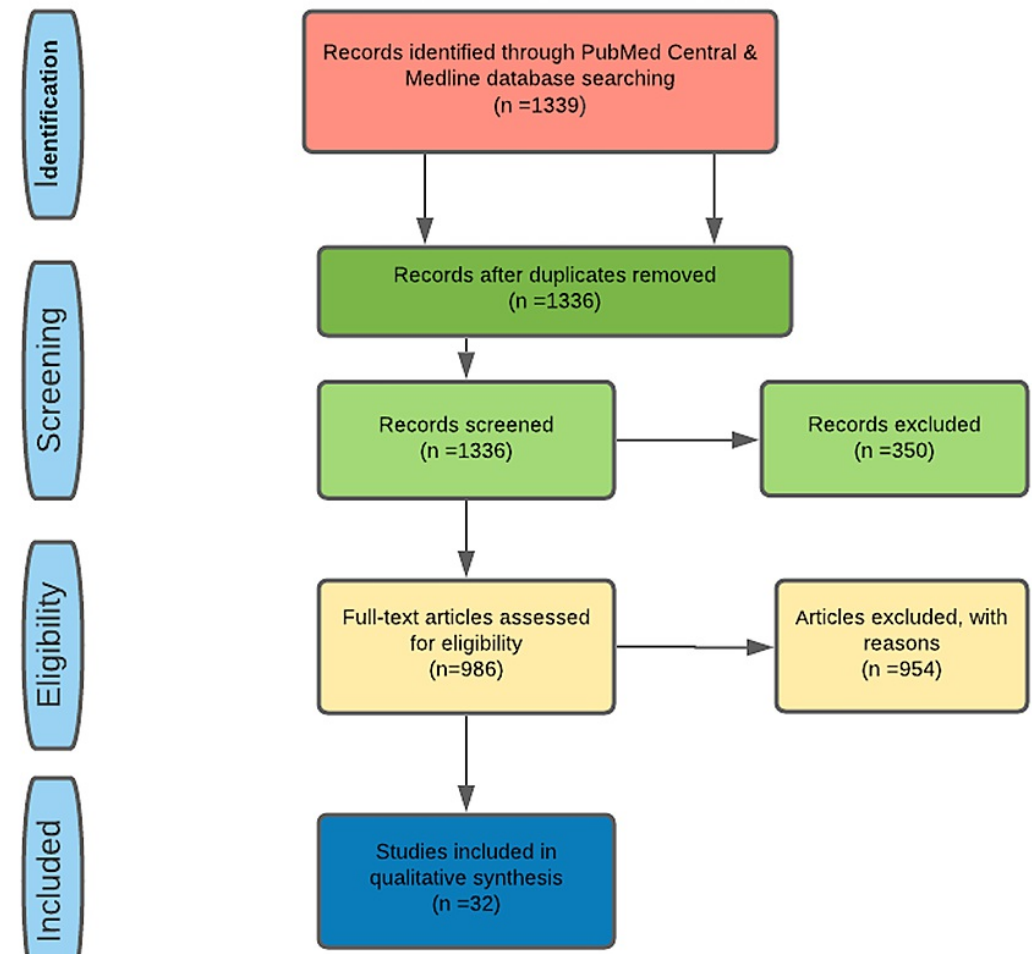

FIGURE 2: Search Strategy PRISMA Flow Diagram

PRISMA = Preferred Reporting Items for Systematic Reviews and Meta-Analyses

Quality of Study

According to each specific guideline, two authors checked each study's quality in the review without blinding to authorship or journal for the risk of bias. We found all studies of high quality according to the quality assessment tools.

Types of Studies and Outcomes Measured

The final 32 studies contain randomized clinical trials (RCT), observational studies, non-randomized clinical trials, case reports, traditional reviews, editorial letters, and systematic review/metanalysis.

The outcome measures that were used to compare CCBs and adenosine in the treatment of PSVT were (1) rate of reversion to normal sinus rhythm, (2) time to immediate reversion to sinus rhythm, (3) cost of medicine, (4) minor and major side effects, and (5) recurrence of arrhythmia.

\section{Results}




\section{Cureus}

The search identified 1339 potentially relevant studies on PubMed Central and Medline. The majority of studies were excluded on the basis of the relevance of the abstract and title. We used the Mendeley reference manager to remove duplicate studies. No research before 1972 was included. The summary of the final 32 studies shown below in Table 1 .

\begin{tabular}{|c|c|c|c|c|c|c|c|c|}
\hline $\begin{array}{l}\text { Article } \\
\text { no. }\end{array}$ & Author & $\begin{array}{l}\text { Year of } \\
\text { publication }\end{array}$ & $\begin{array}{l}\text { No. of } \\
\text { participants }\end{array}$ & Aim of study & $\begin{array}{l}\text { Quality } \\
\text { assessment }\end{array}$ & $\begin{array}{l}\text { Assessment } \\
\text { score }\end{array}$ & Type of study & Findings \\
\hline 1 & $\begin{array}{l}\text { Schamroth } \\
\text { et al. [13] }\end{array}$ & 1972 & 181 & $\begin{array}{l}\text { Immediate effect of IV verapamil in cardiac } \\
\text { arrhythmias }\end{array}$ & High quality & 7 & $\begin{array}{l}\text { Observational } \\
\text { study }\end{array}$ & $\begin{array}{l}\text { Verapamil for the } \\
\text { immediate control of a } \\
\text { variety of cardiac } \\
\text { arrhythmias has been } \\
\text { excellent }\end{array}$ \\
\hline 2 & $\begin{array}{l}\text { Krikler and } \\
\text { Spurrell } \\
{[14]}\end{array}$ & 1974 & 32 & Verapamil in the treatment of PSVT & High quality & 8 & $\begin{array}{l}\mathrm{SR} / \text { meta- } \\
\text { analysis }\end{array}$ & $\begin{array}{l}\text { Verapamil has been shown } \\
\text { to be a safe and effective } \\
\text { agent for SVT }\end{array}$ \\
\hline 3 & $\begin{array}{l}\text { Vohra et } \\
\text { al. [15] }\end{array}$ & 1974 & 4 & $\begin{array}{l}\text { Cycle length alteration in SVT after } \\
\text { administration of verapamil }\end{array}$ & High quality & 16 & Case report & $\begin{array}{l}\text { Verapamil given by IV route } \\
\text { was of value in the } \\
\text { treatment of SVT }\end{array}$ \\
\hline 4 & $\begin{array}{l}\text { Wellens et } \\
\text { al. [16] }\end{array}$ & 1977 & 10 & $\begin{array}{l}\text { Effect of verapamil studied by program-med } \\
\text { electric-al stimulation of the heart in patients } \\
\text { with SVT }\end{array}$ & High quality & 8 & $\begin{array}{l}\text { Observational } \\
\text { study }\end{array}$ & $\begin{array}{l}\text { Verapamil resulted in a } \\
\text { slowing of the heart rate } \\
\text { during tachycardia }\end{array}$ \\
\hline 5 & $\begin{array}{l}\text { Rabkin et } \\
\text { al. [17] }\end{array}$ & 1980 & 11 & CCB and SVT with COPD & High quality & 7 & $\begin{array}{l}\text { Observational } \\
\text { study }\end{array}$ & $\begin{array}{l}\text { CCB is effective in SVT with } \\
\text { COPD }\end{array}$ \\
\hline 6 & Kenny [18] & 1985 & Nil & CCBs and the heart & High quality & 7 & Editorial letter & $\begin{array}{l}\text { CCB is safe and effective in } \\
\text { Heart diseases }\end{array}$ \\
\hline 7 & Krikler [19] & 1986 & Nil & Verapamil in arrhythmia & High quality & 11 & $\begin{array}{l}\text { Traditional } \\
\text { review }\end{array}$ & Verapamil is highly effective \\
\hline 8 & $\begin{array}{l}\text { Sternbach } \\
\text { et al. [20] }\end{array}$ & 1986 & 11 & IV diltiazem for the treatment of SVT & High quality & 9 & $\begin{array}{l}\text { Traditional } \\
\text { review }\end{array}$ & $\begin{array}{l}\text { Diltiazem is safe and } \\
\text { effective }\end{array}$ \\
\hline 9 & $\begin{array}{l}\text { Gutman } \\
{[21]}\end{array}$ & 1987 & Nil & Selecting a CCB & High quality & 8 & $\begin{array}{l}\text { Traditional } \\
\text { review }\end{array}$ & CCB was good in SVT \\
\hline 10 & $\begin{array}{l}\text { Ornato et } \\
\text { al. [7] }\end{array}$ & 1988 & 16 & Treatm-ent of PSVT in ED & High quality & 7 & $\begin{array}{l}\text { Traditional } \\
\text { review }\end{array}$ & CCB was safe in old age \\
\hline 11 & $\begin{array}{l}\text { DiMarco et } \\
\text { al. [22] }\end{array}$ & 1990 & 357 & AD for PSVT and comparison with VM & High quality & 7 & $\mathrm{RCT}$ & $\begin{array}{l}\text { Both } A D \text { and } C C B \text { were } \\
\text { equal in efficacy }\end{array}$ \\
\hline 12 & $\begin{array}{l}\text { Byerly et } \\
\text { al. [23] }\end{array}$ & 1991 & 2 & Verapa-mil in treatm-ent of matern-al PSVT & High quality & 10 & Case report & $\begin{array}{l}\text { CCB was safe in pregnant } \\
\text { patients }\end{array}$ \\
\hline 13 & $\begin{array}{l}\text { Hood and } \\
\text { Smith [24] }\end{array}$ & 1992 & 25 & $A D$ vs. verapamil in the treatment of SVT & High quality & 7 & $\mathrm{RCT}$ & $\begin{array}{l}A D \text { was better than } \mathrm{CCB} \text { in } \\
\text { the treatment of SVT }\end{array}$ \\
\hline 14 & $\begin{array}{l}\text { Dougherty } \\
\text { et al. [25] }\end{array}$ & 1992 & 87 & Acute conversion of PSVT with iv diltiazem & High quality & 7 & $\mathrm{RCT}$ & $\begin{array}{l}\text { Diltiazem is effective in } \\
\text { PSVT }\end{array}$ \\
\hline 15 & Peitz [26] & 1993 & Nil & IV diltiazem rather than verapamil in PSVT & High quality & 8 & Editorial letter & $\begin{array}{l}\text { Diltiazem was effective in } \\
\text { PSVT }\end{array}$ \\
\hline 16 & $\begin{array}{l}\text { Madsen et } \\
\text { al. [27] }\end{array}$ & 1995 & 191 & $\begin{array}{l}\text { AD and verapamil for SVT in the prehospital } \\
\text { setting }\end{array}$ & High quality & 7 & $\begin{array}{l}\text { Observational } \\
\text { study }\end{array}$ & $\begin{array}{l}\text { Verapamil and } A D \text { are equal } \\
\text { in efficacy }\end{array}$ \\
\hline 17 & $\begin{array}{l}\text { Brady et } \\
\text { al. [28] }\end{array}$ & 1996 & 211 & $\begin{array}{l}\text { Treatment of out of hospital SVT AD vs. } \\
\text { verapamil }\end{array}$ & High quality & 8 & $\begin{array}{l}\text { Observational } \\
\text { study }\end{array}$ & $\begin{array}{l}\text { Both } A D \text { and verapamil } \\
\text { were equal in efficacy }\end{array}$ \\
\hline 18 & $\begin{array}{l}\text { Ou et al. } \\
\text { [29] }\end{array}$ & 2004 & 1 & $\begin{array}{l}\text { Choosing CCB for pregnant women with } \\
\text { PSVT }\end{array}$ & High quality & 14 & Case report & $\begin{array}{l}\text { CCB is safe in pregnant } \\
\text { patients }\end{array}$ \\
\hline 19 & $\begin{array}{l}\text { Holdgate } \\
\text { and Foo } \\
{[10]}\end{array}$ & 2006 & 577 & $A D$ vs. CCB for treatment of SVT in adults & High quality & 12 & $\begin{array}{l}\text { SR/meta- } \\
\text { analysis }\end{array}$ & $\begin{array}{l}\text { Both } \mathrm{AD} \text { and } \mathrm{CCB} \text { were } \\
\text { equal in efficacy }\end{array}$ \\
\hline
\end{tabular}




\section{Cureus}

\begin{tabular}{|c|c|c|c|c|c|c|c|c|}
\hline 20 & $\begin{array}{l}\text { Anugwo et } \\
\text { al. [30] }\end{array}$ & 2007 & Nil & AD vs. CCB for SVT & High quality & 7 & Editorial letter & $A D$, the first line of drug \\
\hline 21 & $\begin{array}{l}\text { Lim et al. } \\
\text { [31] }\end{array}$ & 2009 & 233 & Slow iv CCB vs. iv $A D$ in treatment of SVT & High quality & 8 & RCT & $A D$, the first line of drug \\
\hline 22 & $\begin{array}{l}\text { Turkoglu } \\
\text { et al. [32] }\end{array}$ & 2009 & 74 & $\begin{array}{l}\text { verapamil and } A D \text { in termination of sustain-ed } \\
\text { SVT }\end{array}$ & High quality & 8 & RCT & $\begin{array}{l}\text { CCB was found highly } \\
\text { effective }\end{array}$ \\
\hline 23 & $\begin{array}{l}\text { Colucci et } \\
\text { al. [3] }\end{array}$ & 2010 & Nil & $\begin{array}{l}\text { Common types of SVT: diagnosis and } \\
\text { management }\end{array}$ & High quality & 8 & $\begin{array}{l}\text { Traditional } \\
\text { review }\end{array}$ & $\begin{array}{l}\text { Ablation is overall better for } \\
\text { the treatment of SVT }\end{array}$ \\
\hline 24 & $\begin{array}{l}\text { Ghosh et } \\
\text { al. [33] }\end{array}$ & 2011 & Nil & $\begin{array}{l}\text { Acute treatment of maternal SVT in } \\
\text { pregnancy }\end{array}$ & High quality & 10 & $\begin{array}{l}\text { Traditional } \\
\text { review }\end{array}$ & $\begin{array}{l}\text { AD was a safe choice in } \\
\text { pregnancy }\end{array}$ \\
\hline 25 & $\begin{array}{l}\text { Smith et } \\
\text { al. [8] }\end{array}$ & 2014 & 933 & $\begin{array}{l}\text { Prehospital management of SVT in Victoria } \\
\text { Australia }\end{array}$ & High quality & 7 & $\begin{array}{l}\text { Observational } \\
\text { study }\end{array}$ & $\begin{array}{l}\text { Underutilisation of } \\
\text { therapies }\end{array}$ \\
\hline 26 & $\begin{array}{l}\text { Sohinki } \\
\text { and } \\
\text { Obel [6] }\end{array}$ & 2014 & Nil & Current trends in SVT management & High quality & 9 & $\begin{array}{l}\text { Traditional } \\
\text { review }\end{array}$ & $\begin{array}{l}\text { Ablation, overall better to } \\
\text { treat SVT }\end{array}$ \\
\hline 27 & $\begin{array}{l}\text { Dogan et } \\
\text { al. [34] }\end{array}$ & 2015 & 77 & AD or diltiazem in SVT in Emergency Dept. & High quality & 7 & $\begin{array}{l}\text { Observational } \\
\text { study }\end{array}$ & $\begin{array}{l}\text { Diltiazem was a better } \\
\text { option than } A D\end{array}$ \\
\hline 28 & Helton [2] & 2015 & Nil & $\begin{array}{l}\text { Diagnosis and management of common types } \\
\text { of SVT }\end{array}$ & High quality & 8 & $\begin{array}{l}\text { Traditional } \\
\text { review }\end{array}$ & $\begin{array}{l}\text { Ablation is an overall better } \\
\text { option to treat SVT }\end{array}$ \\
\hline 29 & $\begin{array}{l}\text { Shaker et } \\
\text { al. [11] }\end{array}$ & 2015 & 92 & Oral ver-apamil in PSVT recurre-nce control & High quality & 9 & RCT & $\begin{array}{l}\text { Use of CCB after AD in SVT } \\
\text { was recommended }\end{array}$ \\
\hline 30 & $\begin{array}{l}\text { Alabed et } \\
\text { al. [4] }\end{array}$ & 2017 & 622 & $A D$ vs $\mathrm{CCB}$ for $\mathrm{SVT}$ & High quality & 10 & $\begin{array}{l}\mathrm{SR} / \text { meta- } \\
\text { analysis }\end{array}$ & $\begin{array}{l}\text { Both } A D \text { and } C C B \text { were } \\
\text { equal in efficacy }\end{array}$ \\
\hline 31 & $\begin{array}{l}\text { Brubaker } \\
\text { et al. [5] }\end{array}$ & 2018 & Nil & Alterna-te treatm-ent option for PSVT & High quality & 8 & $\begin{array}{l}\text { Traditional } \\
\text { review }\end{array}$ & $\begin{array}{l}\text { Both } \mathrm{AD} \text { and } \mathrm{CCB} \text { were } \\
\text { equal in efficacy }\end{array}$ \\
\hline 32 & $\begin{array}{l}\text { Kotodia et } \\
\text { al. [12] }\end{array}$ & 2020 & Nil & $\begin{array}{l}\text { SVT: An overview of diagnosis and } \\
\text { management }\end{array}$ & High quality & 7 & $\begin{array}{l}\text { Traditional } \\
\text { review }\end{array}$ & $\begin{array}{l}\text { ECG has a key role in the } \\
\text { long-term treatment of SVT }\end{array}$ \\
\hline
\end{tabular}

\section{TABLE 1: Summary of Included Studies}

$\mathrm{AD}=$ adenosine, $\mathrm{CCB}=$ calcium channel blockers, $\mathrm{RCT}=$ randomiazed control trials, $\mathrm{SR}=$ systematic review, $\mathrm{SVT}=$ supraventricular tachycardia, $\mathrm{PSVT}=$ paroxysmal SVT, COPD= chronic obstructive pulmonary disease, $\mathrm{ECG}=$ electrocardiogram, $\mathrm{VM}=$ verapamil, $\mathrm{DM}=$ diltiazem, $\mathrm{IV}=\mathrm{intravenous}$

The outcome was 32 studies included, 350 studies removed after applying inclusion and exclusion criteria, and 954 studies removed based on the abstract and title. The final 32 studies consisted of systematic review/metanalysis, literature reviews, observational studies, editorial letters, randomized controlled trials, and case report/case series. We included studies done in the hospitals and few studies showing data related to prehospital settings, with a population of adults and children. The included case report/case series focused on pregnant patients. The total number of patients was 3111 in the final 32 studies. Studies were ranked high quality based on the score of quality assessment tools, and the cut-off score was equal to or more than seven.

The research question was "are calcium channel blockers a better choice than adenosine in supraventricular tachycardia?"

\section{Inclusion and Exclusion Criteria}

The human studies only in the English language were included and the studies before 1972 and animal studies were excluded.

Bias risk in included studies: Through quality assessment tools, two authors evaluated the risk of selection bias by assessing randomization and allocation concealment. They ranked performance, detection, and attrition bias by assessing blinding to treatment, blinding to outcome assessment, and converting each study to high risk, low risk, and unclear risk.

\section{Discussion}


The purpose of this review is to compare the safety and efficacy of CCBs with adenosine in patients presenting with PSVT. Studies in this article include prehospital, hospital-based patients from childhood to adulthood and pregnant patients experiencing PSVT. This article focuses on the following five points: (1) rate of reversion to normal sinus rhythm, (2) time to immediate reversion to sinus rhythm, (3) minor and significant side effects, (4) recurrence of arrhythmia, and (5) cost of medicine.

The most commonly found type of PSVT in the general population is AVRNRT [35]. In AVRNT, P-waves are challenging to see on the electrocardiogram strip (ECG) due to more or less the same time activation of both atria and ventricle [11]. Either P-waves present as a pseudo-R-wave in lead V1 or a pseudo-S' deflection in inferior leads, but P-waves can be subdued. Pseudo-R-wave is a more critical ECG finding and having high sensitivity regarding diagnosis [36]. Another finding on ECG is an aVL notch, which is any positive deflection at the end of the Q-wave, $\mathrm{R}$-wave, and S-wave (QRS) complex during tachycardia but absent in normal sinus rhythm [34].

\section{Adenosine}

Adenosine has been established as the first-line drug treatment of PSVT due to its comparatively short halflife and safe drug profile. Most clinicians are now using it not only for a therapeutic purpose but also for diagnostic purposes [26]. Türkolu et al. found the appearance of ventricular complexes during the termination of AVNRT, which was more related to adenosine than CCBs [32]. The recommended dosage of adenosine and calcium channel blockers is shown below in Table 2.

\begin{tabular}{|l|l|l|}
\hline Drug & Initial intravenous dose & Further dosing if unsuccessful \\
\hline Diltiazem & $0.25 \mathrm{mg} / \mathrm{kg}$ over $2 \mathrm{mins}$ & Further $0.35 \mathrm{mg} / \mathrm{kg}$ after $15 \mathrm{mins}$ \\
\hline Verapamil & $5-10 \mathrm{mg}$ over $5 \mathrm{mins}$ & Further $5-10 \mathrm{mg}$ after $5 \mathrm{mins}$ \\
\hline Adenosine & $6 \mathrm{mg}$ stat & Further $12 \mathrm{mg}$ after $1-2$ mins \\
\hline
\end{tabular}

TABLE 2: Showing the Dosing for Adenosine and Calcium Channel Blockers.

Studies have shown that adenosine prevents sinus node automaticity, suppresses atrioventricular node conduction, refractoriness, and some drug-induced ventricular arrhythmias [22-37].

\section{Calcium channel blockers}

In cardiac and smooth muscle, CCBs block calcium movements across the cell membrane. CCBs prevent smooth muscle contraction during the depolarization phase, leading to decreased cardiac muscle tone and myocardial contractility [38]. Verapamil and diltiazem are the most commonly used CCBs in the treatment of PSVT. CCBs are contraindicated in patients with atrioventricular blocks, except for first-degree, sick sinus syndrome and digoxin toxicity [21]. Oral verapamil has shown a good response for prophylaxis of AVNRT [19]. Due to its quick action, Wellens et al. used intravenous (IV) verapamil as the first drug of choice for AVNRT after the failure of vagal maneuvers [16]. Krikler and Spurrell documented the rapid conversion of PSVT into sinus rhythm with IV verapamil [14]. Anugwom et al. recommended the use of CCBs if PSVT came back with the initial use of adenosine [30]. CCBs are also known to be beneficial in treating pulmonary hypertension and hypertrophic cardiomyopathy [18]. Dougherty et al. found that hypotension was the most common side effect of diltiazem [25]. Sternbach et al. also showed that intravenous (IV) diltiazem can be as effective and a safe alternative to IV verapamil for AVNRT [20].

\section{Adenosine vs. calcium channel blockers}

In one study, two of 11 identified patients had PSVT and were treated with verapamil. With a background history of ischemic cardiac disease, one patient who suffered from a transient atrioventricular block had to be installed with a radiofrequency pacemaker and coronary sinus catheter [13]. In a case report, four patients received IV verapamil, and all converted to sinus rhythm; however, the review was to see morphological changes in ECG after verapamil administration [15].

Two prospective, double-blind, randomized, placebo-controlled trials showed that sequential adenosine injections ( $6 \mathrm{mg}$ and $12 \mathrm{mg}$ ) produced the same highly effective verapamil results with $5 \mathrm{mg}$ and $7.5 \mathrm{mg}$. However, one-third of patients suffered from a few adverse reactions but of brief duration. The conversion rate was quick with both drugs, but re-initiation of arrhythmia was more common with adenosine use [17].

A total of 25 of 32 patients received adenosine and verapamil. Adenosine was quick in producing results with brief side effects; however, re-initiation of arrhythmia occurred in two patients out of 14 in a 
randomized double-crossover trial. In contrast, three of 11 patients treated with verapamil did not convert to sinus rhythm due to failure to terminate tachycardia in two and hypotension in one patient. A total of 17 patients were treated with adenosine, but 13 experienced side effects of drug-like chest tightness, feelings of electric shock, and flushing with the conversion dose. The study supported adenosine as the first-line treatment for PSVT due to the drugs` short life of a few seconds, therefore having less myocardial depression than verapamil [24].

Verapamil showed $64 \%$ successful results in the prehospital setting during the verapamil period, converting SVT to sinus rhythm, while adenosine had $78 \%$ successful results. In this prehospital setting, paramedics received instructions from hospital-based physicians. The study found that the physicians were more interested in adenosine versus verapamil. SVT was defined as either AVNRT and AVRT with a heart rate between 160 and 240 with sudden onset. Verapamil caused $29 \%$ of side effects, including hypotension. On the other hand, adenosine caused $45 \%$ side effects, but none required emergency treatment. One limitation of this study was that paramedics and hospital-based physicians misdiagnosed $41 \%$ of SVT confirmed with cardiologists [27].

In another prehospital study, verapamil was given in 52 patients with SVT, 43 converted to sinus rhythm, but 17 of 43 had a recurrence of SVT, two in the prehospital setting and 15 in the emergency department [28]. Adenosine was given to 87 patients and 60 patients converted to sinus rhythm. Twenty-five of 60 patients showed SVT recurrence, two out of the hospital, and 23 in the hospital. In another study, drugs were given in different time durations and three out of four patients experienced minor side effects. One had prolonged bradycardia due to prior use of dipyridamole in the adenosine group. Two patients had ventricular tachycardia, ventricular fibrillation, and hypotension seen in one patient each. However, the conversion rate was high with verapamil in the first dose, but the second and third dose rate of conversion was high in adenosine. The study also found a higher adenosine price compared to verapamil [28].

In one prospective randomized controlled clinical trial, patients presented with SVT. Verapamil and diltiazem were used and compared with adenosine. Overall, adenosine showed an $86.5 \%$ conversion rate. In contrast, verapamil and diltiazem both had a $97.9 \%$ and $98.1 \%$ conversion rate, respectively. One patient experienced hypotension secondary to verapamil. Minor side effects were common with adenosine, as seen in $76 \%$ of patients. SVT recurrence was seen in two patients with adenosine, one with diltiazem, and none in verapamil in post-drug two hours. Overall treatment cost was high in adenosine followed by diltiazem and verapamil [31].

In another study, 92 patients were recruited in a randomized clinical trial. One group had adenosine only and the other group had adenosine/verapamil. Both groups were observed for two hours after treatment. The results showed $45 \%$ recurrence in the adenosine group and $28 \%$ recurrence in the adenosine/verapamil group. Two patients experienced minor side effects in the adenosine group, and one patient in the adenosine/verapamil group developed reduced systolic blood pressure [11].

\section{Interpretation and analysis}

Based on the data analyzed in Table 3, adenosine has a high conversion rate and quick mechanism of action in converting PSVT into sinus rhythm than CCBs; however, it is also associated with a higher cost and a higher recurrence of arrhythmia. 


\section{Cureus}

\begin{tabular}{|c|c|c|c|c|c|c|}
\hline $\begin{array}{l}\text { Author } \\
\text { name }\end{array}$ & $\begin{array}{l}\text { Rate of reversion } \\
\text { to normal sinus } \\
\text { rhythm }\end{array}$ & $\begin{array}{l}\text { Time to } \\
\text { immediate } \\
\text { reversion to } \\
\text { sinus rhythm }\end{array}$ & $\begin{array}{l}\text { Minor and major side } \\
\text { effects }\end{array}$ & $\begin{array}{l}\text { Recurrence of } \\
\text { arrhythmia }\end{array}$ & $\begin{array}{l}\text { Cost of } \\
\text { medicine }\end{array}$ & Type of study \\
\hline $\begin{array}{l}\text { DiMarco } \\
\text { et al. } \\
\text { [22] }\end{array}$ & $\begin{array}{l}\text { Both } A D \text { and } C C B \\
\text { have an equal } \\
\text { rate of reversion }\end{array}$ & $\begin{array}{l}\text { Both } A D \text { and } \\
\text { CCB quick in } \\
\text { time to } \\
\text { reversion }\end{array}$ & $\begin{array}{l}\text { AD=more minor } \\
\text { effects } C C B=\text { less } \\
\text { minor effects+ major } \\
\text { effects }\end{array}$ & $\begin{array}{l}\text { AD was related to } \\
\text { recurrence CCB } \\
\text { showed no } \\
\text { recurrence }\end{array}$ & $\begin{array}{l}\text { no } \\
\text { comment }\end{array}$ & $\begin{array}{l}\text { Two prospective, } \\
\text { double-blind, } \\
\text { randomized, placebo- } \\
\text { controlled trials }\end{array}$ \\
\hline $\begin{array}{l}\text { Hood } \\
\text { and } \\
\text { Smith et } \\
\text { al. [24] }\end{array}$ & $\begin{array}{l}A D \text { has more rate } \\
\text { of reversion than } \\
C C B\end{array}$ & $\begin{array}{l}A D \text { was quicker } \\
\text { than } C C B\end{array}$ & $A D=$ minor effects & $\begin{array}{l}\text { AD was related to } \\
\text { recurrence CCB } \\
\text { showed no } \\
\text { recurrence }\end{array}$ & $\begin{array}{l}\text { no } \\
\text { comment }\end{array}$ & $\begin{array}{l}\text { Randomized double- } \\
\text { crossover trial }\end{array}$ \\
\hline $\begin{array}{l}\text { Madsen } \\
\text { et al. } \\
\text { [27] }\end{array}$ & $\begin{array}{l}\text { AD has more rate } \\
\text { of reversion than } \\
\text { CCB }\end{array}$ & No comment & $\begin{array}{l}A D=\text { more minor } \\
\text { effects } C C B=\text { less }\end{array}$ & $\begin{array}{l}\text { AD high recurrence } \\
\text { CCB has less } \\
\text { recurrence }\end{array}$ & $\begin{array}{l}\mathrm{AD}=\text { high } \\
\text { cost } \\
\text { CCB=less }\end{array}$ & $\begin{array}{l}12 \text { months chart review } \\
\text { of } A D \text { and } C C B s \\
\text { administrations }\end{array}$ \\
\hline $\begin{array}{l}\text { Brady et } \\
\text { al. [28] }\end{array}$ & $\begin{array}{l}A D=\text { less in the } \\
\text { first dose } \\
C C B=\text { high in the } \\
\text { first dose }\end{array}$ & $\begin{array}{l}A D \text { was quicker } \\
\text { than } C C B\end{array}$ & $\begin{array}{l}A D=\text { more minor } \\
\text { effects } C C B=l e s s \\
\text { minor effect+ Major } \\
\text { effects }\end{array}$ & $\begin{array}{l}A D=\text { recurrence } \\
C C B=\text { recurrence }\end{array}$ & $\begin{array}{l}\text { AD=high } \\
\text { cost } \\
\text { CCB=less }\end{array}$ & $\begin{array}{l}\text { A comparison of } \\
\text { prospective } A D \text { use } \\
\text { with prospective CCBs } \\
\text { use }\end{array}$ \\
\hline $\begin{array}{l}\text { Lim et } \\
\text { al. [31] }\end{array}$ & $\begin{array}{l}A D=\text { less } \\
C C B=\text { high }\end{array}$ & $\begin{array}{l}A D \text { was quicker } \\
\text { than } \mathrm{CCB}\end{array}$ & $\begin{array}{l}A D=\text { more minor } \\
\text { effects } C C B=\text { less }\end{array}$ & $\begin{array}{l}A D=\text { recurrence } \\
C C B=\text { recurrence }\end{array}$ & $\begin{array}{l}\text { AD=high } \\
\text { cost } \\
\text { CCB=less }\end{array}$ & $\begin{array}{l}\text { Prospective } \\
\text { randomized controlled } \\
\text { clinical trial }\end{array}$ \\
\hline
\end{tabular}

\section{TABLE 3: Comparison of Studies}

$\mathrm{AD}=$ adenosine, $\mathrm{CCBs}=$ calcium channel blocker

\section{Pregnancy and PSVT}

A case report documented the successful conversion of narrow complex, regular SVT without delta wave in a pregnant patient with verapamil. Still, it was unsuccessful with the same patient even a week later. The second time, a dropped maternal blood pressure was recorded; however, no ill effect occurred on the fetus on both occasions [23]. Madsen et al. reported an out-of-hospital conversion of SVT to sinus rhythm with adenosine in a thirty-week pregnant patient with no adverse effects seen [27]. Verapamil has also shown excellent results, lacking fetal and maternal side effects [39]. Ghosh et al. found adenosine more successful than CCBs and recommend using adenosine first. If not successful, especially in the second and thirdtrimester, beta-blockers should be used before verapamil, and both mother and fetus need to be monitored [33]. Ou et al. assumed that calcium channel blockers were preferable to conventional tocolytic agents in preterm labor cases with PSVT [29].

\section{Limitations}

Our reviews' significant limitations included that only studies in the English language were included. Articles available in other languages that were excluded may have additional information to improve this paper's quality.

\section{Conclusions}

Adenosine is the recommended first-line drug treatment for paroxysmal supraventricular tachycardia (PSVT), a benign arrhythmia. Adenosine and calcium channel blockers (CCBs) showed promising results regarding safety and efficacy. Adenosine has a comparatively short half-life and quick mechanism of action; however, it is also associated with a higher drug cost, unpleasant side effects, and a higher recurrence of arrhythmia.

Slow intravenous CCBs can convert PSVT into sinus rhythm, provided no limitations and contraindications to the use of CCBs. We found different suggestions about treatment options for PSVT. A timely review of the ECG can make a difference in the treatment of PSVT. This review found that both adenosine and CCBs are good options in PSVT treatment. But adenosine is having clear advantages over CCBs and first drug of choice in the treatment of PSVT. Our recommendation is, after the successful termination of PSVT with adenosine, oral CCBs can be given if patients are suitable candidates for CCBs. We strongly recommend for future researchers do the study on it. In this way, we can avoid hospital stays, further costs of medications, 
and re-initiating arrhythmia.

\section{Additional Information \\ Disclosures}

Conflicts of interest: In compliance with the ICMJE uniform disclosure form, all authors declare the following: Payment/services info: All authors have declared that no financial support was received from any organization for the submitted work. Financial relationships: All authors have declared that they have no financial relationships at present or within the previous three years with any organizations that might have an interest in the submitted work. Other relationships: All authors have declared that there are no other relationships or activities that could appear to have influenced the submitted work.

\section{References}

1. Heart rhythm disorders. (2020). Accessed: December 1, 2020: https://upbeat.org/heart-rhythm-disorders.

2. Helton MR: Diagnosis and management of common types of supraventricular tachycardia . Am Fam Physician. 2015, 92:793-800.

3. Colucci RA, Silver MJ, Shubrook J: Common types of supraventricular tachycardia: diagnosis and management. Am Fam Physician. 2010, 82:942-952.

4. Alabed S, Sabouni A, Providencia R, Atallah E, Qintar M, Chico TJ: Adenosine versus intravenous calcium channel antagonists for supraventricular tachycardia. Cochrane Database Syst Rev. 2017, 10:CD005154. 10.1002/14651858.CD005154.pub4

5. Brubaker S, Long B, Koyfman A: Alternative treatment options for atrioventricular-nodal-reentry tachycardia: an emergency medicine review. J Emerg Med. 2018, 54:198-206. 10.1016/j.jemermed.2017.10.003

6. Sohinki D, Obel OA: Current trends in supraventricular tachycardia management . Ochsner J. 2014, 14:586595.

7. Ornato JP, Hallagan LF, Reese WA, Clark RF, Tayal VS, Garnett AR, Gonzalez ER: Treatment of paroxysmal supraventricular tachycardia in the emergency department by clinical decision analysis. Am J Emerg Med. 1988, 6:555-560. 10.1016/0735-6757(88)90090-3

8. Smith G, McD Taylor D, Morgans A, Cameron P: Prehospital management of supraventricular tachycardia in Victoria, Australia: epidemiology and effectiveness of therapies. Emerg Med Australas. 2014, 26:350-355. 10.1111/1742-6723.12248

9. Hondeghem LM, Roden DM: Agents used in cardiac arrhythmias . Basic and Clinical Pharmacology. Sixth Edition. Katzung BG (ed): Prentice-Hall International, CT, USA; 1995.

10. Holdgate A, Foo A: Adenosine versus intravenous calcium channel antagonists for the treatment of supraventricular tachycardia in adults. Cochrane Database Syst Rev. 2006, CD005154. 10.1002/14651858.CD005154.pub2

11. Shaker H, Jahanian F, Fathi M, Zare M: Oral verapamil in paroxysmal supraventricular tachycardia recurrence control: a randomized clinical trial. Ther Adv Cardiovasc Dis. 2015, 9:4-9. $10.1177 / 1753944714553425$

12. Kotadia ID, Williams SE, O'Neill M: Supraventricular tachycardia: an overview of diagnosis and management. Clin Med (Lond). 2020, 20:43-47. 10.7861/clinmed.cme.20.1.3

13. Schamroth L, Krikler DM, Garrett C: Immediate effects of intravenous verapamil in cardiac arrhythmias . Br Med J. 1972, 1:660-662. 10.1136/bmj.1.5801.660

14. Krikler DM, Spurrell RA: Verapamil in the treatment of paroxysmal supraventricular tachycardia . Postgrad Med J. 1974, 50:447-453. 10.1136/pgmj.50.585.447

15. Vohra J, Hunt D, Stuckey J, Sloman G: Cycle length alternation in supraventricular tachycardia after administration of verapamil. Br Heart J. 1974, 36:570-576. 10.1136/hrt.36.6.570

16. Wellens HJ, Tan SL, Bär FW, Düren DR, Lie KI, Dohmen HM: Effect of verapamil studied by programmed electrical stimulation of the heart in patients with paroxysmal re-entrant supraventricular tachycardia. $\mathrm{Br}$ Heart J. 1977, 39:1058-1066. 10.1136/hrt.39.10.1058

17. Rabkin SW, Tomlinson C, Corbett BN, Cuddy TE: Verapamil and supraventricular tachyarrhythmias: beneficial effect in patients with chronic pulmonary disease. Can Med Assoc J. 1980, 122:64-68.

18. Kenny J: Calcium channel blocking agents and the heart. Br Med J (Clin Res Ed). 1985, 291:1150-1152. 10.1136/bmj.291.6503.1150

19. Krikler DM: Verapamil in arrhythmia. Br J Clin Pharmacol. 1986, 21:183-189. 10.1111/j.13652125.1986.tb02869.x

20. Sternbach GL, Schroeder JS, Eliastam M, Beier-Scott L: Intravenous diltiazem for the treatment of supraventricular tachycardia. Clin Cardiol. 1986, 9:145-149. 10.1002/clc.4960090403

21. Gutman E: Selecting a calcium channel-blocking agent. Can Fam Physician. 1987, 33:1019-1023.

22. DiMarco JP, Miles W, Akhtar M, et al.: Adenosine for paroxysmal supraventricular tachycardia: dose ranging and comparison with verapamil. Assessment in placebo-controlled, multicenter trials. The Adenosine for PSVT Study Group. Ann Intern Med. 1990, 113:104-110. 10.7326/0003-4819-113-2-104

23. Byerly WG, Hartmann A, Foster DE, Tannenbaum AK: Verapamil in the treatment of maternal paroxysmal supraventricular tachycardia. Ann Emerg Med. 1991, 20:552-554. 10.1016/s0196-0644(05)81615-4

24. Hood MA, Smith WM: Adenosine versus verapamil in the treatment of supraventricular tachycardia: a randomized double-crossover trial. Am Heart J. 1992, 123:1543-1549. 10.1016/0002-8703(92)90807-8

25. Dougherty AH, Jackman WM, Naccarelli GV, Friday KJ, Dias VC: Acute conversion of paroxysmal supraventricular tachycardia with intravenous diltiazem. IV Diltiazem Study Group. Am J Cardiol. 1992, 70:587-592. 10.1016/0002-9149(92)90196-6

26. Peitz TJ: Intravenous diltiazem hydrochloride rather than verapamil for resistant paroxysmal supraventricular tachycardia. West J Med. 1993, 159:598-599. 
27. Madsen CD, Pointer JE, Lynch TG: A comparison of adenosine and verapamil for the treatment of supraventricular tachycardia in the prehospital setting. Ann Emerg Med. 1995, 25:649-655. 10.1016/S01960644(95)70179-6

28. Brady WJ Jr, DeBehnke DJ, Wickman LL, Lindbeck G: Treatment of out-of-hospital supraventricular tachycardia: adenosine vs verapamil. Acad Emerg Med. 1996, 3:574-585. 10.1111/j.15532712.1996.tb03467.x

29. Ou KY, Yang CH, Tsai EM, Lai WT, Su JW: Choosing calcium channel blockers for pregnant women with paroxysmal supraventricular tachycardia and preterm labor: a case report. Kaohsiung J Med Sci. 2004, 20:457-460. 10.1016/s1607-551x(09)70185-8

30. Anugwom C, Sulangi S, Dachs R: Adenosine vs. calcium channel blockers for supraventricular tachycardia . Am Fam Physician. 2007, 75:1653-1654.

31. Lim SH, Anantharaman V, Teo WS, Chan YH: Slow infusion of calcium channel blockers compared with intravenous adenosine in the emergency treatment of supraventricular tachycardia. Resuscitation. 2009, 80:523-528. 10.1016/j.resuscitation.2009.01.017

32. Türkoğlu C, Oztürk M, Aliyev F, Firatli I, Incesoy N: Electrophysiologic characteristics of wide QRS complexes during pharmacologic termination of sustained supraventricular tachycardias with verapamil and adenosine: observations from electrophysiologic study. Ann Noninvasive Electrocardiol. 2009, 14:375-380. 10.1111/j.1542-474X.2009.00329.X

33. Ghosh N, Luk A, Derzko C, Dorian P, Chow CM: The acute treatment of maternal supraventricular tachycardias during pregnancy: a review of the literature. J Obstet Gynaecol Canada. 2011, 33:17-23.

34. Dogan H, Ozucelik DN, Aciksari K, et al.: To decide medical therapy according to ECG criteria in patients with supraventricular tachycardia in emergency department: adenosine or diltiazem. Int J Clin Exp Med. 2015, 8:9692-9699.

35. Orejarena LA, Vidaillet H Jr, DeStefano F, Nordstrom DL, Vierkant RA, Smith PN, Hayes JJ: Paroxysmal supraventricular tachycardia in the general population. J Am Coll Cardiol. 1998, 31:150-157. 10.1016/s07351097(97)00422-1

36. Katritsis DG, Camm AJ: Classification and differential diagnosis of atrioventricular nodal re-entrant tachycardia. Europace. 2006, 8:29-36. 10.1093/europace/euj010

37. Lerman BB, Belardinelli L, West GA, Berne RM, DiMarco JP: Adenosine-sensitive ventricular tachycardia: evidence suggesting cyclic AMP-mediated triggered activity. Circulation. 1986, 74:270-280. 10.1161/01.cir.74.2.270

38. Stone PH, Antman EM, Muller JE, Braunwald E: Calcium channel blocking agents in the treatment of cardiovascular disorders. Part II: hemodynamic effects and clinical applications. Ann Intern Med. 1980, 93:886-904. 10.7326/0003-4819-93-6-886

39. Tan HL, Lie KI: Treatment of tachyarrhythmias during pregnancy and lactation . Eur Heart J. 2001, 22:458464. 10.1053/euhj.2000.2130 